\title{
Download Q
}

https://doi.org/10.17721/2308-135 X .2019.46. $\underline{\text { 43-47 }}$

UDC 378.1:615.825

Belousova Natalya Vladimirovna, Candidate of Geographical Sciences, Associate Professor, N ational

aviation University of Kyiv, Ukraine e-mail:

belousova-69@ukr.net

ANALYSIS OF PREPAREDNESS OF TOURIST AGENCIES OF UKRAINE TO WORK WITH INCLUSIVE TOURISTS

Goal. Taking into account socio-economic factors, to give an analysis of the readiness of modern Ukrainian travel agencies for the purpose of creating adapted tourist routes for inclusive tourists taking into account their special needs and to identify the problems of providing tourist services to people with inclusions, especially those with a disability of different nosologies.

Method. Analytical, comparative-geographical and synthetic methods were used. 
Results. Analyzing the state of work of modern Ukrainian travel agencies for the development and introduction of tourist routes for inclusive tourists, especially for people with disabilities, the reluctance of travel agencies to deal with this segment of tourists on economic, medical and purely social aspects was revealed.

Scientific novelty. The state of readiness of travel agencies for work with inclusive tourists is analyzed, reasons of low level of interest of tour operators in developing routes for inclusive tourists, especially people with disabilities are revealed.

Practical significance. Materials of publication can be used during the educational process in higher educational institutions that train specialists for the Ukrainian tourist industry, practical activities of tour operators and agencies.

Key words: tourism, inclusive tourists, people with disabilities, travel agencies.

References:

1. Belousova N.V. Theoretical aspects of the development of inclusive rehabilitation and social tourism in Ukraine. Scientific journal «Scientific notes of Sumy State Pedagogical University. Geographic Sciences». - Sumy: SumgPU named after A.S.Makarenko, 9th issue, 2018 C.205-213; 
2. Belousova N.V. Inclusive tourism in the system of rehabilitation geography: from theory to practice: monograph / Belousova N.V. - M., TALKO, 2018. - 346 p.

3. International Diplacement Monitoring Center. Latest IDP numbers bycountry: [Electronic resource]. - Access mod:

http://www.internal-displacement.org/database 